\title{
1. LEARNING CAREERS AND TRANSFORMATIVE LEARNING
}

\author{
Challenges of Learning and Work in Neoliberal Spaces
}

\section{INTRODUCTION}

Many adults have been 'locked out' of opportunities by their previous schooling, life experiences and continuing financial barriers. Disability and literacy difficulties also exclude many from the twin desires of education and work. Education and training are widely seen as providing keys to work and jobs. A number of the chapters in this book present broader understandings of how students experience the world that is unlocked by training and work that in turn lead to new identities and careers.

This chapter outlines a vision of education that 'unlocks' its emancipatory potential as articulated by Paulo Freire (critical pedagogy) and Jack Mezirow (transformative learning) and a vision of education that is an antidote to neoliberal policies. This chapter explores work in the global political and economic project known as neoliberalism and outlines current understandings of neoliberalism in a way that illustrates how public policy drives educational agendas towards addressing the needs of the market for workers rather than for the broader needs of individuals, communities and society. Mezirow and Freire are allies in this, as is Axel Honneth. The following chapters in this book are studies of continuities and discontinuities and of persistence and these issues are explored in the world of education and work.

Adults are resilient and if barriers such as finance are minimised and learning supports enhanced they will persist in education (Fleming, Loxley, \& Finnegan, 2017). Real learning can be achieved and learning needs met by education, especially as it is an important source of recognition for learners. Recognition is a psychological and political spark that ignites and sustains learning that is deeply satisfying, critical, developmental and capable of delivering the educational promise of freedom and emancipation. It is the key that unlocks individual and social potential.

\section{NEOLIBERALISM}

As a recent iteration of capitalism, neoliberalism emphasises privatisation, downsizing the state as arbiter of the public good; encourages markets to supply everything; curtails organised labour often with legislation and dismantles the 
welfare state. The state is restructured to reflect the interests of business. According to Harvey (2005, p. 2) neoliberalism is;

A theory of political economic practices that proposes that human wellbeing can best be advanced by liberating individual entrepreneurial freedoms and skills within an institutional framework characterized by strong private property rights, free markets and free trade.

Neoliberalism subjects the social functions of the state to economic calculation as if public services were private companies that regulated education, health, social security and employment (Bauman, 2014, p. 17). The state is compelled to cede functions they once considered their domain into the care of already deregulated market forces. Citizens lose faith in the ability of governments to deliver on their promises. The certainties of employment are demolished (or at least called into question) by part-time or zero-hours contracts thus adding to the insecurity of temporary employment.

Everything is subject to review so as to constantly reset priorities based on perceived shortages of public funding. Everything has become debatable, questionable, shaky, destined to remain standing or be wiped out with a stroke of the pen in response to more urgent needs, budget problems and compliance with European regulations (Bauman \& Bordoni, 2014, p. 67). Everyone is expected to provide for themselves without burdening others (Bauman \& Bordoni, 2014, p. 57). Consumerism 'may lubricate the wheels of the economy but sprinkles sand into the bearings of morality' (Bauman \& Bardoni, 2014, p. 153). Discontinuities are embedded in the system.

We are required to do more with less and manage with scarce resources and adjustments - a euphemism for deep cuts in public expenditure, including education. Governments are preoccupied with austerity even though there is evidence that austerity makes the problem worse (Blyth, 2013). Austerity is first and foremost a transfer of wealth from the lower and middle classes to the classes above them. It furthers the neoliberal project of increasing inequality under the guise of freeing lower socio-economic groups from their social welfare supported unwillingness to work. These ideas are worked out in greater detail by Giroux (2014), Piketty (2014), and Sen (2015).

Neoliberalism does not aim to increase well-being but drives for a more competitive society and economy. Education is required to meet the needs of the economy for skilled workers and to re-focus its curriculum to become business friendly and produce graduates who are more 'work-ready'. State investment is expected to increase productivity and innovation, while investments in education are adjusted downward. The potential of lifelong learning to respond to the learning needs of active citizens is neglected (Fleming, 2011) and instead is implicated in the push to have everyone upskill and contribute to the economy (CEC, 2000). This context is important for this chapter and the following chapters in this book where the impacts of how work and education are reconfigured to fit the neoliberal agenda are addressed. 


\section{ROLE OF ADULT EDUCATION}

Education has always been associated with progress, with freedom, democracy, justice and care. In its Manifesto for Adult Learning for the 21st Century the European Association for the Education of Adults (EAEA, 2016) asserts that adult education has a role in changing lives and transforming society. It sees adult education as a human right and a common good. But it needs investment. The Manifesto (p. 3) supports the traditional aims of adult education including citizenship, democracy, emancipation as well as life skills, health benefits, social cohesion and equality. Reskilling for work, second chance education and entrepreneurship are not neglected (pp. 4-5). By the conclusion of the document there is little that adult education cannot achieve about sustainability and other social, political, economic targets and aspirations.

How then is the rhetoric at odds with reality and public policy? Governments seem to be suspicious of learning that does not have an economic focus. The EU average participation rate for adult education is 10 per cent - though some countries have achieved rates between 25 and 30 per cent, e.g. Denmark, Sweden, Finland (European Commission, 2016, p. 80). Romania, Bulgaria, Croatia and Slovakia have participation rates in the range 1 to 3 per cent. Adult learners might be excused for thinking that their second chance opportunities are few and far between.

A number of current policy debates ask how the situation can be justified where the system is producing more graduates than the job market requires (Murphy, 2017; Sweeney, 2016). This conversation sees no point in taxi-drivers having PhDs! This concern about the excess supply of graduates, the resulting impact on the economy and the declining economic returns on education disconnect education from its value as a means of social mobility and advancement (Murphy, 2017).

Sweeney, a senior policy analyst at the National Economic and Social Forum (NESC) agrees that there are unresolved policy issues (state funding of education) concerning the learning needs and projects that adults undertake including how to create lives of fulfilment in families and society. Without learning and education it is difficult to achieve democracy, and participation in society and freedom. The implication is that the state abandons higher education for the masses and instead provide lower level skills for workers mostly through its further and adult education provision.

In contrast, in an interview in The Nation, Chantel Mouffe asserts that the gulf between the popular classes and the wealthy is growing and that there has been an oligarchization of politics (Shahid, 2016). Workers have been 'abandoned by neoliberalism' and suffer losses resulting from globalization (Shahid, 2016, p. 4). Politics has failed to respond and has no discourse about peoples' genuine problems. Mouffe is one of the preeminent theorists on democracy and social movements and she proposes a concerted reaction to this trend by "creating a bond between those struggles in a way that recognises the specificities of different struggles' but also by fiercely recognising the commonalities and solidarities among the various struggles (Shahid, 2016, p. 7). This would involve recognising workers and other rights 
that have been taken away over recent years and engaging in a 'war of position' where 'progressive forces could build real influence in civil society, the dominant institutions, main stream culture and the media' (Shahid, 2016, p. 12). Education would have a social intent and not be just be preoccupied with training for jobs.

In recent times the field of education has been enriched by significant contributions to the understanding of adult education by Freire and Mezirow. They have defined the meaning and possibilities of adult learning in their respective theories of critical pedagogy and of transformative learning.

Mezirow (1978) defines one kind of learning that involves skills and techniques that for many lead to jobs. It is essential learning. Plumbers, accountants, farmers all kinds of scientists and engineers engage in technical learning that is about how best to do things. How to build a bridge in all its complexity is a good example of this kind of learning. These skills are taught mainly by demonstration. Technical learning offers freedom as it involves mastery and the ability to overcome the restrictions imposed on humans by nature.

Another kind of learning involves the humanities and social sciences, e.g. history, psychology, literature, etc. It involves understanding communications between people and understanding one self. Understanding is not a skill to be demonstrated but an ability to see things from the perspectives of others. Empathy and perspective taking are central and are taught through role play, case study and the kinds of discussions that one associates with adult education classes and seminars.

We each think and behave and make meaning within a paradigm constructed through the experiences we have in individual lives and through the impact of culture and society. This gives each a unique meaning making paradigm or frame of reference as Mezirow calls it. It is the educational process involved in changing these frames of reference that is known as Mezirow's Transformative Learning (Mezirow, 1978, 2000). For example, my frame of reference just happens to be white, male, middle class, Christian etc. and changing this is what Mezirow means by transformative learning.

Mezirow researched the learning experiences of adults returning to education and found that the learning process followed a path that normally began with a disorienting dilemma. This was followed by critical reflection on the genesis of the psycho-cultural assumptions that formed their frames of reference. The transformative process concluded with the adoption of new frames of reference and acting on the basis of these new ones. To become a feminist is a good example of such a transformation. Transformative learning is, according to Mezirow (2000, pp. 7-8):

the process by which we transform our taken-for-granted frames of reference (meaning perspectives, habits of mind, mind-sets) to make them more inclusive, discriminating, open, emotionally capable of change, and reflective so that they may generate beliefs and opinions that will prove more true or justified to guide action. 
Mezirow's theory of transformative learning clearly indicates the possibilities that can be realised through adult education.

Mezirow relied heavily on Jürgen Habermas for two elements of his theory that gave his theory academic rigor. First, the understanding of the kinds of learning outlined above - technical-skills, understanding and emancipatory or transformative learning (Fleming, 2002). Second, an understanding of the nature of the discourses or conversations that would lead to transformative learning, involving critical reflection. These Socratic conversations are linked to freedom and democratic will formation and follow rules that create open free debates in which all participants have the right to participate, ask questions and clarify their position on the understanding that the only force exercised is the force of the better argument. When these rules are followed the discussions approximate to an ideal speech situation (Habermas) in which people's real needs may emerge.

By relying on Habermas, Mezirow gave transformative learning theory an emancipatory intent that was further enhanced by his reliance on Paulo Freire. Both support knowledge and learning that go beyond the skills and mutual understandings of communications and propose an emancipatory process akin to ideology critique (Morrow \& Torres, 2001).

In a less radical but interesting contribution Kreber (2015) identifies traditions in adult education that forge connections between skills learning on the one hand and democracy and social action on the other. The education of workers as not only members of an economy but as members of a democratic society was part of the mission of the Workers Education Association (WEA). Kreber highlights the historical link between work and the building of a life around that work that is a useful and productive life for individuals, families and society (Kreber, 2015, p. 102).

Relying on John Dewey and Hannah Arendt, Kreber shows how workers are motivated not just by pay but by the wish to do a good job (2015, p. 104). This involves not only being effective and efficient, not just following Health and Safety or Quality Assurance requirements but involves recognising the ethical and social dimensions of work. She takes hairdressers as an example. They are not only skilful operators but provide social cohesion in communities. As they produce wellgroomed customers this has important social and personal consequences at work and elsewhere. At a minimum self-image is at stake. Appearance matters. This contributes to identity formation and enhancement.

Using hairdressing as her example may overstate the case slightly but she does provide an interesting understanding of the importance of what is usually seen as low paid, low skilled and unregulated work. She sees workers as civic agents, facilitating social interactions and community discussion. This is a public good and workers become enablers of democracy. 'Education might foster among future professionals a sense as civic agents capable of facilitating and participating in public deliberations' (Kreber, 2015, p. 111). Building on Biesta (2012), she goes on to explore the possibility that professionals may participate in activities that involve a concern for the 'public qualities of human togetherness' (Biesta, 2012, p. 683). 
These issues are visible in many of the following chapters where learning has consequences for the individuals and for society.

\section{HONNETH}

Both Mezirow and Freire maintain a link with the emancipatory intent of critical theory. However, critical theory has moved on from the first generation (Marcuse and Fromm) and the second generation (Habermas) to the third generation that includes Honneth. Honneth moves beyond Habermas by expanding the theory of communicative action on which Mezirow relied. He shows how critical reflection, that in Mezirow's usage is often critiqued as overly rational, (Cranton \& Taylor, 2012) requires and presupposes recognition. Without mutual recognition there can be no critical reflection. At the level of the family, recognition is given and received, for example, in the attachment experience between the infant and the adult carer. In this the parent recognises the fear or anxiety of the child and under the impact of a caring and empathetic response the child grows and develops (Fleming, 2016a).

Recognition is given and received in the intimate relations of the family, in communities, in society and at work (echoes of Hegel in this). The task of critical theory, according to Honneth, is to identify experiences in society that contain 'systemexploding energies and motivations' in pursuit of freedom and justice (Fraser \& Honneth, 2003, p. 242). He offers 'a link between the social causes of widespread feelings of injustice and the normative objectives of emancipatory movements' (Fraser \& Honneth, 2003, p. 113). Honneth re-writes critical theory so that damaged recognition is the pathology to be overcome, rather than distorted communication. Social change is driven by inadequate forms of recognition and internal (psychic) conflict leads to social change. The social and personal are connected. The individual search for identity is not isolated from political and social contexts and events. Distortions in identity are the motivation for struggle and social conflict and this moves the debate about emancipation away from the perceived highly cognitive and rational interest of Habermas (and indeed Mezirow) toward an alternative theory of intersubjectivity. It implies that not only is the personal political but the political is personal. Transformative learning is both personal and social (Fleming, 2014). In the following chapters of this book so many varied interventions are seen as transformative and based on this understanding the learning can be both personal and political.

Transformative learning and communicative action involve more than following linguistic rules of discourse (Habermas, 1987, p. 121). They involve mutuality and intersubjectivity (Honneth, 1995, pp. 92-95). The struggle for recognition, based on experiences of disrespect and the need for self-esteem, explains social development according to Honneth (1995, p. 92);

It is by the way of the morally motivated struggles of social groups - their collective attempt to establish institutionally and culturally, expanded forms of recognition - that the normatively directional change of societies proceeds. 
When citizens with a disability are recognised by the economy or the community or society (in its practices and laws) this moment is developmental at both personal and social levels. When Travellers are given status as an ethnic minority or gay rights are legislated for (the right to marry) these systemic policy and legislative moments are not only political but are profoundly developmental at an individual level. We have become accustomed to saying the personal is political. The political is personal. Work also provides moments of recognition and unfortunately (like school) too many moments of misrecognition. In a later chapter Fernando and King identify how hope is reclaimed through education. An enhanced learner identity is achieved according to Kastner in a later chapter.

\section{THE FREEDOM TURN OF HONNETH}

These ideas are of particular interest to educators looking for new ways of expressing a counter possibility for adult education - counter that is to dominant neoliberal imperatives. But Honneth goes beyond Habermas by seeking a broader vision of democracy involving not only the political sphere but emancipated families and a socialized market (Honneth, 2014, p. 345). The realisations of freedom in any one of these areas depends on its realisation in the others as democratic citizens, emancipated families and ethical markets 'mutually influence each other, because the properties of one cannot be realized without the other two' (Honneth, 2014, pp. 330-331). For Honneth (2014, p. 15) freedom is the key value of modern life;

Of all the ethical values prevailing and competing for dominance in modern society, only one has been capable of leaving a truly lasting impression on our institutional order: freedom, i.e. the autonomy of the individual ... all modern ethical ideals have been placed under the spell of freedom ....

Freedom involves the ability to realise one's own desires, intentions and values in the social environment of roles and obligations. As one might anticipate, individual and social freedom are connected - and not in some vague or superficial way but essentially. In addition, he asserts that markets, interpersonal relationships and the spaces of public politics are best understood as places of potential social freedom. Places such as work, friendships, family, work, laws, are all justified only if they promote, support and bring about a free society for all. These institutions can be evaluated as successful to the extent that they encourage and bring about social freedom and a better life. Education and the right to education (though not referred to by Honneth) are part of that emancipatory project. Later chapters in this book highlight the development of autonomy, identity and social freedom experienced by students in Spain and Portugal on a literacy programme.

Social freedom is connected to the sphere of markets that offer co-operative activities that are in the interest of all participants and these involve offering goods for sale and jobs. In markets there are of course consumer rights; regulations as to what can be sold and how; regulations about pricing, wages, imports, illegal commodities 
and so on. There are also regulations about fairness in business transactions (Honneth, 2014, p. 202). These areas of economic activity are structured by the values they serve by meeting peoples' needs for goods (Honneth, 2014, p. 199) and recognising their achievements at work. Honneth outlines changes in society that contribute to disconnecting the markets from social freedom. Neoliberalism does not increase or support social freedom (2014, pp. 176-177) and is a social misdevelopment that makes individual identity development more difficult to achieve. Later chapters refer to and emphasise the potential negative impact for students. Any explicit critique of neoliberalism should not be interpreted as a negation of the important role that markets play in social, community and political life as of right.

The most important sphere of social freedom is what he calls the 'We' of democratic will formation (2014, p. 253). This leads Honneth to his theory of democracy where democratic interactions enable citizens to make their lives and conditions better through a process of discourse or democratic will formation (2014, p. 254). Again, with reference to Habermas and his radical discursive democracy, the democratic state acts as an agent of the democratic public sphere (2014, pp. 305-307). This suggests that learning (and teaching) for the development of the 'we' of democratic discourse may be a vital task of education and a necessary one for transformative learning. One's identity development is not merely an individual task but necessarily involves a social dimension. Educators may be at risk of not perceiving how social and political many outcomes are for students studying what are on first appearance quite individual learning projects.

Social movements have been important in enhancing democratic moments of the public sphere and current indignations and insurgent social movements in places such as Barcelona, Athens and Wall Street are typical of the expanded 'we' that are, in Honneth's view, spheres of social freedom. Only through agreed and mutually supportive cooperations with others can there be political freedom. Freedom of this kind is inherently social as it cannot be realised if one is not involved in the 'we' of democratic will formation where the same weight is afforded to all contributions of citizens (p. 261). This is reminiscent of Dewey's affirmation that 'democracy is a name for a way of life of free and enriching communication' (Dewey, 1954, p. 148). A new vision of adult education would involve supporting through tuition, seminars and its entire pedagogy and indeed its management systems a collaborative environment that supports and teaches how to be democratic.

\section{IMPLICATIONS AND DISCUSSION}

These ideas of Honneth have had little impact on education apart from a few (Brown \& Murphy, 2012; Huttunen, 2008; Murphy \& Brown, 2012). Some work has been done on the connection with transformative learning (Fleming, 2014). Transformative learning requires critical reflection and recognition becomes central to the learning process. In order to engage in the critical discourse associated with transformative learning and critical pedagogy we now paraphrase Honneth who asserts that the 
formation of democratic discussions requires three forms of self-relating or identity. We need caring and loving individuals (teachers). It requires recognition of the reciprocal nature of legal rights. And thirdly, a democratic discursive society requires the reciprocal recognition provided by work and solidarity. Freire's culture circles are good examples of how these processes might operate in practice (Souto-Manning, 2010). Everything is connected.

This 'recognition turn' suggests that the high rationality of the critique required by transformative learning is 'softened' by this understanding of the interpersonal recognition that underpins the democratic discourse of a learning environment. Teaching might usefully address the struggles of students for recognition as motivations for their learning. Without altering the importance of critical reflection for transformative learning and critical pedagogy there is now the possibility of reframing these learning theories so that rational discourse is seen as based on an interpersonal process of support and recognition that builds self-confidence, self-respect and self-esteem. Mezirow (and Dewey and Freire and Habermas) see democratic participation as an important means of self-development that produces individuals who are more tolerant of difference, sensitive to reciprocity and better able to engage in discourse (Mezirow, 2003, p. 60). It is important not to sink into a sentimental subjectivity here but build on this understanding; this is a precondition for rational discourse and this does not involve a loss of rigor or the ambition to remain within the emancipatory agenda of critical theory.

The emphasis on whether learning is individual or social (Fleming, 2016b, p. 78) can be re-configured in a similar way to how Freire reconfigured the dualisms of subject/object, teacher/learner and reflection/action best expressed in his concept of praxis (1972, p. 75). The perceived individualism of Mezirow's theory can now be reframed as built on a fundamentally intersubjective process of mutual recognition. These relations of mutuality are preconditions for self-realisation, critical reflection, identity development and transformative learning. Recognition and emancipation are connected; recognition becomes the foundation on which emancipatory learning and social change are based. This implies that learning, whether in transformative learning or in adult education in general, is best supported by interactions that are not only respectful but that explicitly recognise the individual worth of each individual along with the aspirations and dreams that prompt their struggle for recognition. The pursuit of identity is both an individual learning and developmental project as well as a social, political and economic task. Freire reconfigured the relationship between the traditional dualism of thinking and action by relying on the concept of praxis (Freire, 1972, p. 60). He also connected teaching and learning in a similar way (Freire, 1998, p. 29) so that these apparent opposites were defined as connected dialectically: 'there is no teaching without learning' (Freire, 1998, pp. 29-48).

The process of transformative learning commences with a 'disorienting dilemma' and includes a stage where one's individual 'problem' becomes identified with a major/significant social issue (Mezirow, 2000, p. 22). In Mezirow's work this perplexity normally involves a disconnect and discomfort between old inadequate 
frames of reference and the possibility offered by new ones. The dilemma for the learner is whether to stay with old ways of making meaning that have lost their ability to usefully guide understanding and action or search for new ones. The struggle for recognition acts as a disorienting dilemma. It motivates the search for new meaning schemes and identities. The struggle for recognition is a form of perplexity (Dewey, 1997, p. 11). It has within it the possibility that this may be the paradigmatic form of disorienting dilemma. The dilemma involves whether to stay in a world circumscribed by old experiences of misrecognition or respond to the struggle to be recognised and acknowledged through learning. This search for new meanings is found in social struggles, new social movements and in adult education. Of necessity, there are continuities and discontinuities in these explorations.

One of the stages in the transformative process involves making connections between one's own individual problem (that may have prompted learning) and broader social issues. From this study of Honneth it is proposed that personal problems are intimately connected to broader social issues. Many of the following chapters outline such issues and can be seen in this way. The connection is not just an empirically grounded finding in research on transformation theory but is a philosophically essential step in properly interpreting the world. Now the political is personal and the learning process necessarily involves making this connection. At an obvious level, adult education requires the ability to perceive the world in this way - the personal and political and social are connected.

Adult education now becomes a learning project with the practical intent of increasing freedom, justice, care and equality in the spheres of family, law and work and involves transformation not just of the individual but of society also.

It is important to attend to teaching as a process of mutual recognition between teacher and learner. Teaching that is informed in this way has the potential to strengthen identity development. With the current emphasis on functional learning, competency and behavioural outcomes that are supported by neoliberal states it is important to take seriously the contribution of intersubjectivity in teaching and learning. The motivation to engage in learning becomes less economic, functional and instrumental and more social and potentially transformative, critical and emancipatory. This is achieved not just by an emphasis on critical reflection but on the always presupposed imperative of recognition. This assists in reclaiming the emancipatory potential of adult education that has the long standing intention of bringing about a better society in which to live, grow and create environments in which families can take care of children - and not just a society as a place in which to work. This is evocative of the thoroughly human and humanizing task of education as outlined by Freire in Pedagogy of the Oppressed (1972, p. 21) where he frames critical reflection, dialogue and changing the world as an exercise in love (1972, p. 62).

The critical role of education is to work in solidarity with workers and citizens to insert democratic imperatives into the system world. The foundations of democracy are under threat from the monopoly of technical and instrumental reason in society. The forces of technical control must be made subject to the consensus of acting 
citizens who in dialogue redeem the power of reflection and intersubjectivity. The preoccupation shifts from prioritising how to get things done to realising genuine democracy. By adding insights from the third generation of critical theorists the vision that recognises the struggle of people to exercise their right to learn is developmental and a necessary condition for emancipation. The reliance on Honneth is mostly about securing a theoretical base for concepts that are intersubjective, political and social and connected with each other.

\section{CONCLUSION}

Many adult education programmes are quite individual in their focus. These include many of those described in later chapters, on literacy (Silva, DeLourdes Dionísio \& Cunha), on book clubs (Leal), on textile design (Broadhead) and taking on board prior learning (Paulos). Even in the various groups the focus is individual whether disadvantaged, non-traditional, underserved, low qualified, at risk students (King, Eamer \& Ammar), students with mental health issues (Fernando \& King), or prisoners (Pillera). Others (Thunborg \& Bron; Tenirio-Rodriguez, Padilla-Carmona \& González-Monteagudo) pay attention to the links between education and labour market transitions and to the ways that higher education contributes to the stratification of the academic labour market. Issues concerning teacher education is the topic in other chapters (Thompson \& Wolstencroft; Galimberti \& Ratti). And all appear to focus on individuals.

But it is deceptive because when the experiences are analysed it becomes clear that the transformative learning or increased critical awareness is not just an individual experience but has (whether the programmes perceive this or not) a clear political and/or social dimension. The connection is the experience of recognition. Recognising the students' intelligence and ability as well as providing experiences of friendship, connection and support in open free democratic conversations open at least the possibility that something quite profound is happening. Identities are being forged and equally important the impetus and momentum may be given to realise more democratic moments in classrooms, in families, in communities and at work. This is the opposite to and the antidote to the experiences of being 'locked out' of their desires for education and work.

\section{REFERENCES}

Bauman, Z. (2014). What use is sociology? Cambridge: Polity Press.

Bauman, Z., \& Bordoni, C. (2014). State of crisis. Cambridge: Polity Press.

Biesta, G. J. (2012). Becoming public: Public pedagogy, citizenship and the public sphere. Social and Cultural Geography, 13, 683-697.

Blyth, M. (2013). Austerity: The history of a dangerous idea. Oxford: Oxford University Press.

Bourdieu, P. (1984). Distinction: A social critique of the judgement of taste. London: Routledge.

Brown, T., \& Murphy, M. (2012). The dynamics of student identity: The threats from a neoliberal model and the benefits for a relational pedagogy. In L. West \& A. Bainbridge (Eds.), Psychoanalysis and education: Minding the gap (pp. 217-242). London: Karnak. 


\section{T. FLEMING}

CEC (Commission of the European Community). (2000). A memorandum on lifelong learning: Commission staff working paper. Brussels: European Commission.

Cranton, P., \& Taylor, E. W. (2012). Transforming learning theory: Seeking a more unified theory. In E. W. Taylor, P. Cranton, \& Associates (Eds.), The handbook of transformative learning (pp. 3-20). San Francisco, CA: Jossey-Bass.

Dewey, J. (1954). The public and its problems. Chicago, IL: Swallow Press.

Dewey, J. (1997). How we think. New York, NY: Dover.

European Association for the Education of Adults (EAEA). (2016). Manifesto for adult learning in the 21st century. Brussells: EAEA. Retrieved March 21, 2017, from http://www.eaea.org/media/policyadvocacy/manifesto/manifesto.pdf

European Commission. (2016). Education and training monitor 2016. Retrieved March 25, from https://ec.europa.eu/education/sites/education/files/monitor2016_en.pdf

Fleming, T. (2002). Habermas on civil society, lifeworld and system: Unearthing the social in transformation theory. Teachers College Record On-line, 2002, 1-17. Retrieved June 25, 2015, from http://www.tcrecord.org/content.asp?ContentID=10877

Fleming, T. (2011). Models of lifelong learning: An overview. In M. London (Ed.), Oxford handbook of lifelong learning (pp. 29-39). New York, NY: Oxford University Press.

Fleming, T. (2014). Axel Honneth and the struggle for recognition: Implications for transformative learning. In A. Nicolaides \& D. Holt (Eds.), Spaces of transformation and transformation of space. Proceedings of the 11th international transformative learning conference (pp. 318-324). New York, NY: Teachers College.

Fleming, T. (2016a). Reclaiming the emancipatory potential of adult education: Honneth's critical theory and the struggle for recognition. European Journal for Research on the Education and Learning of Adults, 7(1), 13-24.

Fleming, T. (2016b). The critical theory of Axel Honneth: Implications for transformative learning and higher education. In V. Wang \& P. Cranton (Eds.), Theory and practice of adult and higher education (pp. 63-85). Little Rock: Information Age Publishing.

Fleming, T., Finnegan, F., \& Loxley, A. (2017). Retention in Ireland's higher education institutions. In T. Fleming, A. Loxley, \& F. Finnegan (Eds.), Access and participation in Irish higher education. London: Palgrave Macmillan.

Fraser, N., \& Honneth, A. (2003). Redistribution or recognition? A political-philosophical exchange. London: Verso Books.

Freire, P. (1972). Pedagogy of the oppressed. New York, NY: Seabury.

Freire, P. (1998). Pedagogy of freedom: Ethics, democracy and civic courage. New York, NY: Rowman and Littlefield.

Giroux, H. (2014). Neoliberalism's war on higher education. Chicago, IL: Haymarket.

Habermas, J. (1987). The theory of communicative action: The critique of functionalist reason (Vol. 2). Boston, MA: Beacon.

Harvey, D. (2005). A brief history of neoliberalism. Oxford: Oxford University Press.

Honneth, A. (1995). The struggle for recognition: The moral grammar of social conflicts. Cambridge, MA: MIT Press.

Honneth, A. (2014). Freedom 's right: The social foundations of democratic life. Cambridge: Polity Press.

Huttunen, R. (2008). Habermas, Honneth and education. Köln: Lambert.

Kreber, C. (2015). Transforming employment-oriented education to foster Arendtian action: Rebuilding bridges between community and vocational education. Adult Education Quarterly, 65(2), 100-115.

Mezirow, J. (1978). Perspective transformation. Adult Education, 28, 100-110.

Mezirow, J. (1991). Transformative dimensions of adult learning. San Francisco, CA: Jossey-Bass.

Mezirow, J. (2000). Learning to think like an adult: Core concepts of transformation theory. In J. Mezirow \& Associates (Eds.), Learning as transformation: Critical perspectives on a theory in process (pp. 3-34). San Francisco, CA: Jossey-Bass.

Morrow, R. A., \& Torres, C. A. (2002). Reading Freire and Habermas: Critical pedagogy and transformative social change. New York, NY: Teachers College Press. 
Murphy, M. (2017). Who is to blame for overeducation: Graduates, employers or policy makers? Glasgow: Robert Owen Centre for Educational Change, University of Glasgow. Retrieved on March 24, 2017, from http://robertowencentre.academicblogs.co.uk/who-is-to-blame-for-overeducationgraduates-employers-or-policy-makers/

Murphy, M., \& Brown, T. (2012). Learning as relational: Intersubjectivity and pedagogy in higher education. International Journal of Lifelong Education, 31(5), 643-654.

Piketty, T. (2014). Capital in the twenty-first century. Cambridge, MA: Harvard University Press.

Shahid, W. (2016). America in populist times: An interview with Chantal Mouffe. Retrieved March 24, 2017, from https://www.thenation.com/article/america-in-populist-times-an-interview-with-chantalmouffe/

Sweeney, J. (2016, March 14). Raising the status and quality of further education and training: The labour market as an ally. Paper presented at the Further Education and Training Forum, The National College of Ireland, Dublin.

Sen, A. (2015, June 4). The economic consequences of austerity. New Statesman. Retrieved March 26, 2017, from http://www.newstatesman.com/politics/2015/06/amartya-sen-economic-consequencesausterity

Souto-Manning, M. (2010). Freire, teaching and learning: Culture circles across contexts. New York, NY: Peter Lang.

\section{Ted Fleming}

Columbia University

New York, USA 